\title{
TP53 Gene Mutation Negative
}

National Cancer Institute

\section{Source}

National Cancer Institute. TP53 Gene Mutation Negative. NCI Thesaurus. Code C148092.

A genetic finding indicating that TP53 gene mutations have not been detected in a sample. 